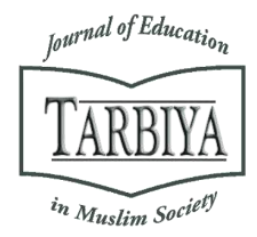

Available online at TARBIYA: Journal of Education in Muslim Society Website:

http://journal.uinjkt.ac.id/index.php/tarbiya

TARBIYA: Journal of Education in Muslim Society, 3(2), 2016, 205-217

\title{
EDUCATION REWARD FOR TEACHER: IMPLEMENTATION STRATEGY TO IMPROVE TEACHER' PERFORMANCE
}

Sri Sarjana ${ }^{1}$, Nur Khayati ${ }^{2}$, Lis Warini ${ }^{3}$

${ }^{1}$ State Vocational High School (SMKN) 1 of Cikarang Barat, Indonesia

${ }^{2}$ State Senior High School (SMAN) 1 of Cikarang Utara, Indonesia

${ }^{3}$ State Junior High School (SMPN) 1 of Mojosongo, Indonesia

E-mail: ${ }^{1}$ srisarjana@gmail.com; ${ }^{2}$ nurkayati.pch@gmail.com; ${ }^{3}$ lis.warini@gmail.com ${ }^{3}$

Received: $05^{\text {th }}$ October 2016; Revised: $10^{\text {th }}$ November 2016; Accepted: $22^{\text {th }}$ December 2016

\section{Abstract}

Reward for teacher became one of the ways to improve teachers' performance for the development of national education. It is an appreciation for teachers based on merit or the excellent performance, given both individually and institutionally in the form of material or appreciation. A competent teachers have the ability, skill, and attitude of work in accordance with established standards. The purposed of this study is to analyze the effect of reward on teachers in creating performance through the optimization of creativity, innovation development and competence. The data were analyzed through triangulation model of transformation that combines qualitative and quantitative methods. The findings indicate that teachers' reward model that able to create performance through increasing the creativity, innovation, and competence. Furthermore, this study is expected to build awareness of the ministry of education in improving the quality of national education systems including the expansion of rewards for teachers who have great working performance in creativity, innovation and competence.

Keywords: reward; teacher' performance; creativity; innovation; competence

\section{Abstrak}

Penghargaan bagi guru menjadi salah satu tuntutan dalam upaya peningkatan prestasi kerja untuk pengembangan kualitas pendidikan nasional. Penghargaan guru merupakan bentuk apresiasi terhadap guru berdasarkan prestasi atau kinerja unggul yang diberikan baik perorangan maupun lembaga dalam bentuk materil maupun lisan. Guru yang kompeten memiliki kemampuan, ketrampilan maupun sikap kerja sesuai dengan standar yang ditetapkan. Tujuan penelitian ini untuk menganalisis pengaruh penghargaan guru dalam rangka menciptakan prestasi kerja melalui optimalisasi kreativitas, pengembangan inovasi dan peningkatan kompetensi. Teknik analisis data menggunakan model triangulasi transformasi yang memadukan metode kualitatif dan kuantitatif. Temuan dalam penelitian ini mengintegrasikan model penghargaan guru yang mampu menciptakan prestasi kerja melalui upaya meningkatkan kreativitas, inovasi, dan kompetensi. Lebih lanjut, penelitian ini mengharapkan kementerian pendidikan nasional lebih berperan aktif dalam meningkatkan kualitas sistem pendidikan nasional diantaranya melalui perluasan pemberian penghargaan bagi guru yang memiliki keunggulan dalam kreativitas, inovasi dan kompetensi.

Kata kunci: penghargaan; prestasi kerja; kreativitas; inovasi; kompetensi

How to Cite : Sarjana, S. Khayati, N. Warini, L. (2016). Education Reward for Teacher: Implementation Strategy to Improve Teacher' Performance. TARBIYA: Journal of Education in Muslim Society, 3(2), 205-217. doi:10.15408/tjems.v3i2.4390.

Permalink/DOI: http://dx.doi.org/10.15408/tjems.v3i2.4390 


\section{Introduction}

Education focuses on self-development, the achievement of the objective of creating a situation which is required by an individual and as an attempt to self-development. Selfdevelopment is creative individual attitudes toward themselves, the creation of oneself in an active process of internal and external affected by a view to change. Various advanced methods of teaching are updated overtime by the high professionalism of teachers through the ability of teachers who have special specifications and professional quality (Ospanova et al, 2015). Each teacher has a lot of demands and expectations of professional and social environment in which teachers have to think again about themselves, teachers also have to determine the long-term goal of pedagogic activity, teacher have to know how students learn, think, feel and deal with. Teachers develop skills to improve customer satisfaction and effectiveness, while also improving the knowledge and skills that encourage their self-esteem. The complexity teachers' tasks demands on competence every day related to student learning, emotional and behavioral characteristics of students (Bukvić, 2014). The main challenge faced by organization in a highly competitive environment right now is to be more creative and more innovative (Luthan, 2011).

Achievment instruments of professional teachers can be seen from the ideal number of teachers, career development, rewards and protection provided. Teachers' competence is measured through the assessment of their performance, continuous professional development and competency tests. One of the constraints of teachers in continuing professional development is due to the difficulty of making scientific work or innovative one. Teacher professional allowance is given for the teacher that able to develop self-competence (Alamsyah,
2015). Basically, the teacher rewards are not only focused on providing professional benefits for certified teachers, but also provide the opportunity for teachers who have added value in terms of creativity, innovation and competence in the development of education in the school system in various levels. Teacher reward in matters related to the provision of professional allowances should also not be determined only from the teacher competency test, but also the measurement of the reward to the teacher should be done comprehensively with the burden and the task of the teacher as an educator at the school in addition to the measurement of teacher competence test itself. The reward of teachers should also be expanded and augmented category and types, not just in formal contexts such as the provision of professional allowances but would be better and has added value in terms of quantity and quality if the rewards a teacher can involve five institutions or education stakeholders both from the main level to the local level which may be facilitated by the government, academic, industry, community and the environment.

Certified teachers' performance has minimal achievement. The numbers of teachers who pass the certification are not directly proportional to the achievements of teachers in teaching. The lack of accomplishment certified teachers a dilemma for education in this country (Munthe, 2013). However, teacher certification is emphasized on the aspect of competence rather than performance. Teacher certification does not create prominent teachers but creating qualified teachers according to their field. To create an achievement for teachers need the stimulus with the aim of making teachers more creative and innovative in order to improve its competence. Stimulus for teachers to be able to excel through a series of competitions, education and training do not merely a formality and routine in the implementation of the project alone but should 
really prioritize aspects of job performance. Through the competition program is one way to create an outstanding teacher and has an advantage in their field.

Efforts to improve the quality of national education threatened to fail. Many educators are reluctant to make innovations in teaching methods and have authority the technology education (Suud, 2012). Creative teachers are always restless and uneasy with its learning strategy, and constantly improve themselves with a variety of action research. Teachers are trying to find the new methods of learning so that the results are very useful for other teachers. Creative teacher is the teacher where they aware of the shortcomings and makes for lifelong learning. The important thing for they are allied with the knowledge for the advancement of education. To be a creative teacher to write a scientific paper required a careful lesson planning, action learning exciting, brilliant process of observation, and reflection with peers that have led to successful learning (Kusumah, 2009). Creativity and innovation education is one indicator of the success of the learning system in school. Improving the quality of education had backdrop of the planning, proceed, and the implementation of a creativity and innovation in the education system. Innovative teacher will result in improvement and change for the better learning systems resulting in improved quality of learning. Getting the teachers to be creative and innovative is the task of governments and all stakeholders in education to improve the quality of education and to achieve the expected goals of national education.

\section{Reward}

Reward is something to be achieved by a person in a working form of compensation issued in the form of energy, expertise or resources (Babatunde, 2013). Rewards include how someone estimable according to the value of the organization. The reward could be given in the form of salary or compliment (as a reward through motivating teachers orally such as an appreciation from the institution) (Tripathy, 2006). The reward system is composed of components of the organization including people, processes, rules and procedures, decisionmaking activities that have involvement in allocating compensation and benefits to employees as a change that can contribute to the organization. The goal of reward system is to attract, retain and motivate qualified employees. The structure of the organization compensation should be fair and consistent to ensure equality of treatment and legal compliance. Reward prize should also be fair to the individual's contribution to the organization to measure objectively (Griffin \& Moorhead, 2014). Reward depends on the performance. Employees perceive that experience, skill, ability, effort, and input to explain the difference in terms of performance therefore paid out according to job duties and appreciation (Robins \& Judge, 2013).

The purpose is to make more rewards to attract, motivate, recognition, straighten the better, loyalty. The principles of reward include transparent and credible, competition, sustainability, meaning clear and easy to understand (Rose, 2014). The purpose of the reward system is to attract, retain and motivate qualified employees and to maintain fair salary structure both internally and externally competitive. Reward has two sides and symbolic value. Reward can be concrete money, indirect compensation or benefits, additional income, rewards and incentives. Some factors such as the impact of motivation, cost, and in accordance with the system of organization must be considered when designing or analyzing a reward system. The effective management of reward systems required the performance associated with rewards. The managing of the reward requires a 
role of some things like flexible reward systems, employee participation in the payroll system, payroll system confidentiality. (Griffin \& Moorhead, 2014). Reward system in the organization is given to motivate unethical behavior (Robin \& Judge, 2013). If employees see a reward system for good performance pay, rewards will strengthen and encourage good performance. Rewards are an important part of organizational justice (Robin \& Judge, 2013).

Strategy reward is the process of policy development and practical impact on the performance of organizations that help to maintain and create interest in a person's aptitude, motivation and perceived value (Armstrong, 2012). An individual should have the motivation to work. Motivation has a specific goal to be achieved. Someone must have enough motivation to set goals to be achieved. To achieve the goal, one must have a commitment with the perception that efforts will produce an effective performance. Performance leads to the reward as expected by the people. Achievement of reward is directed to the purpose of satisfaction for employees. This is related to the value of the individual in remuneration. A person will be satisfied with the benefits granted if more interesting and valuable. The pride of the reward and value of rewards expected to lead to a good quality of the working environment (Hema Malini \& Washington, 2014). Materialistic culture is more likely to see compensation and rewards as the most relevant results in the work, while the relational culture will see the social benefits and status as an important ethical (Robin \& Judge, 2013).

Teachers are not motivated by financial rewards can be replaced with appreciation except money. These rewards include the satisfaction of achievement, recognition, the effect of education is high, learning new skills, and the development of the individual (Tomlinson, 2000). The policy of giving different rewards based on the level of the school. Policies differ based on the location of the reward. Teacher experience is a factor influencing the policies of the reward. Policies of the reward will also vary depending on individual behavior (Joo et al, 2012). Evidence meta-analysis showed individuals in both individualistic and collective cultures prefer equalization rewards (the most effective workers are paid the most) through the same division (all paid the same regardless of performance) (Robin \& Judge, 2013).

\section{Job Performance}

Job performance by Gibson et al. (2006) is the work associated with organizational objectives such as quality, efficiency and other criteria relevant to the effectiveness of work. Job performance is defined by Bennett et al (2006) as measured by the behavior of the individual contribution to achieving organizational effectiveness. Job performance is the behavior of the involvement of employees while at work and contribute to organizational goals (Jex, 2002). Job performance is a real feat achieved by someone. Job performance there are two types of individual achievements and the achievements together or group (Mangkunagara, 2000). Job performance depends on the ability and the environment and motivation (Griffin \& Moorhead, 2014). Best traits predict job performance through awareness and positive selfconcept (Robin \& Judge, 2013).

Performance appraisal by Sirait (2006) is defined as a procedure that includes standardsetting work, assessing employee performance significantly compared with the standard of work that has been established, providing feedback to employees to leave the poor performance and to maintain and even improve the achievements that have been good. To improve performance, the change must occur in every individual (Rothwell \& Kazanas, 2003). Work performance 
related to the results of a process organizational climate, leadership, adequate compensation (Mullins, 2005). Attitudes and behaviors can be predicted from the extent to which people believe job performance will lead to various outcomes (expectations) and the value of (valence) for each individual (Griffin \& Moorhead, 2014). Some social characteristics that can improve work performance included their interdependence, social support, and interaction with other people outside of work. Interdependence, prudence, responsibility, and honesty proved to be a strong predictor of the supervision work performance (Robin \& Judge, 2013).

\section{Innovation}

Innovation is the process of creating and doing new things are introduced to the market as a product, process, or service. Innovation involves every aspect of the organization, from research through development, manufacturing and marketing. One of the biggest challenges the organization is to bring innovative technologies to market needs in a way the reduce cost (Griffin \& Moorhead, 2014). Innovation according Duin (2006) is an idea, practice, or object that is considered by an individual or group. Robbins and Judge (2013) describe that innovation as a special kind of change in which a new idea applied to start or improve a product, process, or service. White and Bruton (2011) defines innovation as a change in which products, processes, materials and new service or repaired, developed and transferred to the company or the market as appropriate. According to Sattler (2011) innovation is a repetitive process initiated by the perception of a new market or a new service opportunity for discovery-based technology, aimed at the development, production, and marketing tasks for business success in discovery that are completely new.
Jeschke and Hees (2013), said innovation is the realization of new ideas that contribute to sustainable change. Pitsis, Simpson and Dehlin (2012) described the concept of innovation: first, as a temporal concept, innovation is creating some changes or adaptation that involve either before, now and after, the means that always talking about the past, present and future. Second, innovation is an idea and occurred in a unique context, a way to know and understand the world.

While Mullins (2005) explains that innovation as a process of renewal and progress in all the major activities of the organization. According to Web (2011) Innovation is the process of creating exceptional value for customers through active listening process. Afuah (2009) added that both product innovation or and business process is a good example of the value creation of the new game, do something different outcome and the price is cheaper. Bessant and Tidd (2011) defined innovation as consistent discovery that characterize the foremost associated with success. Bessant and Tidd (2011) describes the innovation as special tools are mostly businessmen exploit change as an opportunity for a different business or service. It is capable served as discipline, learning, and practice.

Factor in the innovation process according to Schermerhorn et al. (2010) consist of the idea of creation through creativity spontaneous, ingenuity and processing of information. The experiment is an initial stage of building the values and ideas of potential. Determination is the feasibility of identifying costs and benefits. The final application are produce and market new products or services, or to implement a new approach in the operations. The mechanism used to encourage innovation and creativity, criteria naturally can't be determined, customers as the driving quality, the continuous improvement as a learning cycle, emphasizes to 
the optimization of working time in the operationalization of the company, focus on customer needs in the future.

\section{Creativity}

Creativity is an individual's ability to generate new ideas or understand new perspectives on existing ideas. Therefore, creativity can play the role of how a problem situation or decision is defined, alternatives are identified, and how each can be evaluated. (Griffin \& Moorhead, 2014). According to Schermerhorn et al. (2010) creativity is the generation of new ideas or a unique approach to solving the employment problem exploiting employment opportunities. Definition of creativity according to Martin (2008) is a way to create or find new products and valuable. Creativity by Stamm (2008) is an action with the idea as the main idea of the basic actions of individuals. In implementing the idea, the teachers need creativity to take into account the innovation. As it is known, reativity is an important part in innovation, meaning that to crate innovation teachers need creativity to do so. Acton (2013) defines creativity as the process of observing, exploit, and generated new business ideas for social activities and materials. Mumford (2012) defines that creativity is a form of performance or something produced by individuals or groups. According to Runco (2007) creativity is suspected ideas to solve the problem. Robbins and Judge (2013) expressed the opinion that the properties associated with creative individuals are independence, selfconfidence, dare to take risks, have a place internal control, tolerance for ambiguity, requires a low structure and have perseverance.

Creativity organization can be seen as a process in which creativity as an input process that promotes innovation, competition and return on investment (Cook, 1998). Okpara
(2007) explain in more detail the link creativity to innovation that creativity is the root of innovation, where the absence of creativity then there will be an innovation. Beule and Nauwelaerts (2013) describes the organizational creativity can encourage the flow of new ideas for new product development process. With their creativity, it will encourage the creation of a new product or innovation. Creativity involves the incorporation of feedback or ideas from individuals or groups in a new way so that creativity to produce something that is seen by everyone to be something different (Luthan, 2011).

Creativity techniques formation begins from the experience and results of the work of pedagogical skills and creativity in the development of considerable potential for the development of creativity yourself professionally in representing professional activity that will come (Ospanova et al. 2015). Problem solving, innovation, and creativity provide a competitive advantage in today's global marketplace. Leaders must have a creativity skill, provide a climate that encourages creativity and helps people to be creative. Behavior positive encourage creativity all dimensions and there are no significant differences by gender and the material taught by teachers (Ozkal, 2014). Creative learning associated with the discovery of new solutions that can generate new insights to existing problems or understand the issues in more depth during the process of consideration and revision. Creativity requires the use of imagination. When creativity is supported to allow students to make connections in the overall education system that can improve the use of knowledge and capacity flexibly to utilize other sources of informal learning. School is not a place where all knowledge is saved but is regarded as a place where knowledge is developed and propagated (Burke, 2007). Creativity hindered by exams that have time constraints, rigid and inflexible or 
a great program and a lack of time. Inhibit creativity classroom environment with regard to the behavior of teachers who do not want to take the students' ideas into consideration so that the teachers a centralized and limited and does not allow interaction (Fleith, 2000). Provision of prospective teachers through training in environment encourages creativity and provides training related to creativity for teachers and prospective teachers will have a positive impact creativity to encourage behavior in the classroom (Ozkal, 2014).

\section{Competency}

Competency is a very complex system of knowledge, belief, and action and it is a form of a good organization with a specific authority, namely skills, basic skills, and behavioral aspect in general. The complexity of competence encompasses three interrelated dimensions such as cognitive, skills and behavior or values (Weinert, 2001). Crick (2008) describes competence as a complex combination of different knowledge, skills, understanding, values, attitudes and desire to make effective, manifested in the form of human action in the world. Self-competency is the ability as a mirror and to learn from experience, curiosity and doubt, the ability to think holistically in context, think positively, maintain integrity, patience with yourself and others. Social competency is the ability to communicate, to stay behind, open space for students, working together (Požarnik \& Lavric, 2015).

Necessary to understand the pedagogical competency of teachers as a process which is permanently direction to the assessment through the interaction between co-workers, students, parents and others (Ljubetić \& Vranjes, 2008). Analysis of eight core competencies in initiating the learning plan include a commitment to get a scholarship of teaching, research and practice- based reflective teaching, doing a creative approach to the challenges, actively participate in the national and international network, using methods that focus teaching and assessment system is modern, has a capacity in pedagogic leadership, become agents of change in the academic community, have a connection with life outside the community (Požarnik \& Lavric, 2015).

The competency of teachers by law no. $14 / 2005$ about teachers and lecturers includes pedagogical competency, personal competence, professional competence, social competence. Pedagogic competency related to the ability to understand the characteristics or capabilities of the students through various means such as by understanding the cognitive development of students, learning design, and implementation of learning and evaluation of learning to outcomes at the same time student development. Personal competency is one of the personal ability to be possessed by professional teachers in a way that better reflects the personality of self, be prudent and wise, mature and dignified and noble character has to be a good example. Professional competency is one of the elements that must be owned by a teacher that is a way to master the learning material is broad and deep. Social competence is one of the competencies associated with doing a good way to communicate and interact with students, staff, parents of students and the surrounding community.

H1: Creativity, innovation, competency are significantly influenced by rewards

$\mathrm{H} 2$ : Creativity, innovation, competency have a significant effect on performance

H3: Rewards gives positive effect on job performance

H4: Creativity, innovation, competency have significant effect, either directly or through on performance 


\section{Method}

The type of this research is descriptive and verification. Descriptive research aims to obtain an overview of creativity, innovation, competence, rewards, and job performance of teachers. While the verification study aimed to examine the effect between these five variables. The method used in this research is to describe descriptive survey method to explain systematically and the accuracy of the facts and the specific field characteristics and explanatory survey method to perform hypothesis-testing procedure in order to answer the problem formulation and research purposes. Types of this research are causality where the research that indicates the direction of the relationship between variables based on the construction of the research model. Observations use the time coverage is cross-sectional or one shoot, means that the information or data obtained are the result of research conducted in a certain time on October to December, 2015.

The population in this study is all of teachers in Bekasi district as many as 11207 teachers. By using approach Slovin formula:

$$
\mathrm{n}=\frac{\mathrm{N}}{1+\mathrm{Ne}^{2}}
$$

Remarks :

$\mathrm{n}=$ sample size

$\mathrm{N}=$ population size

$\mathrm{e}=$ critical value

Population size $(\mathrm{N})=11207$ and inaccuracy $(e)=5 \%$, obtained large sample size needed $(n)=$ 387. From the above sample size, samples were taken by simple random sampling technique in which every member of the population has an equal chance to be selected into the sample drawn at random through a draw system.

The data were collected through the interview and questionnaires. Interviews were conducted with several teachers to obtain the necessary data, identify and verify the phenomenon gained from observation. A questionnaire was used as a measuring tool or instrument to collect primary data from the teachers in the district of Bekasi. The questionnaire was developed from operational variables of statement with a response interval scale form with the answer 1 (very low) to 5 (high).

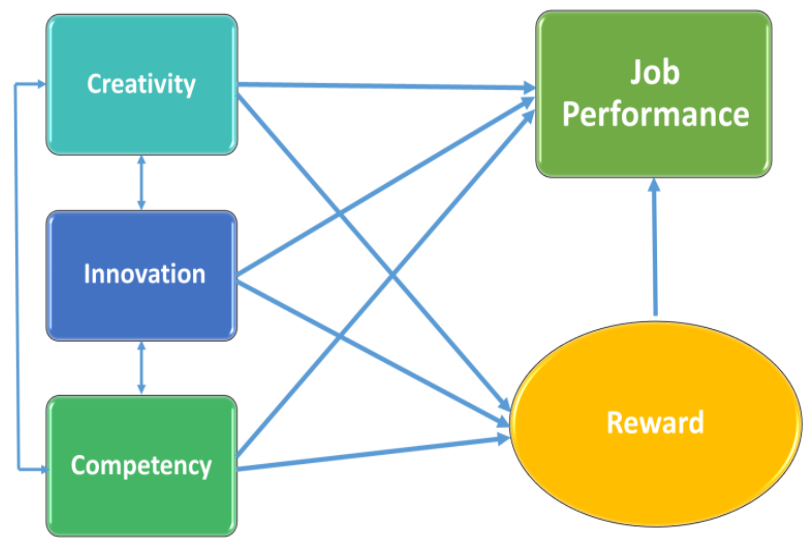

Figure 1. Reward's Model for Teacher

The analysis used in the form of descriptive analysis of the variables that are qualitative and quantitative analysis or verification in the form of hypothesis testing using statistical tests. The combination of the two methods of analysis are expected to be obtained that is comprehensive solution to the problems. Descriptive analysis is used to describe each variable in order to obtain information regarding the perception and understanding of the ministry of national education on the level of creativity of teachers, high and low of teacher innovation, the level of competence for teachers, high and low of reward and jobs performance are achieved. Quantitative and verification analysis is done by using Structural Equation Modeling (SEM) to verify the influence between variables. SEM is used as a research model that is based on the number of teacher sizeable population in Bekasi that sampling in the survey are predicted to represent the whole of the population. The interpretation of the combined analysis by using triangulation model of transformation (Bandur, 2014). 


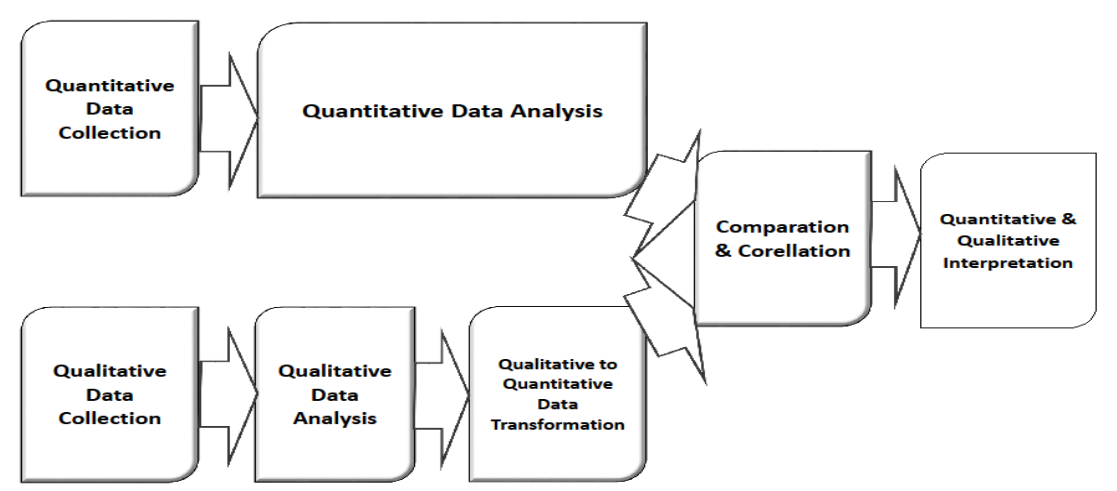

Figure 2. Triangulation Transformation Model (Bandur, 2014)

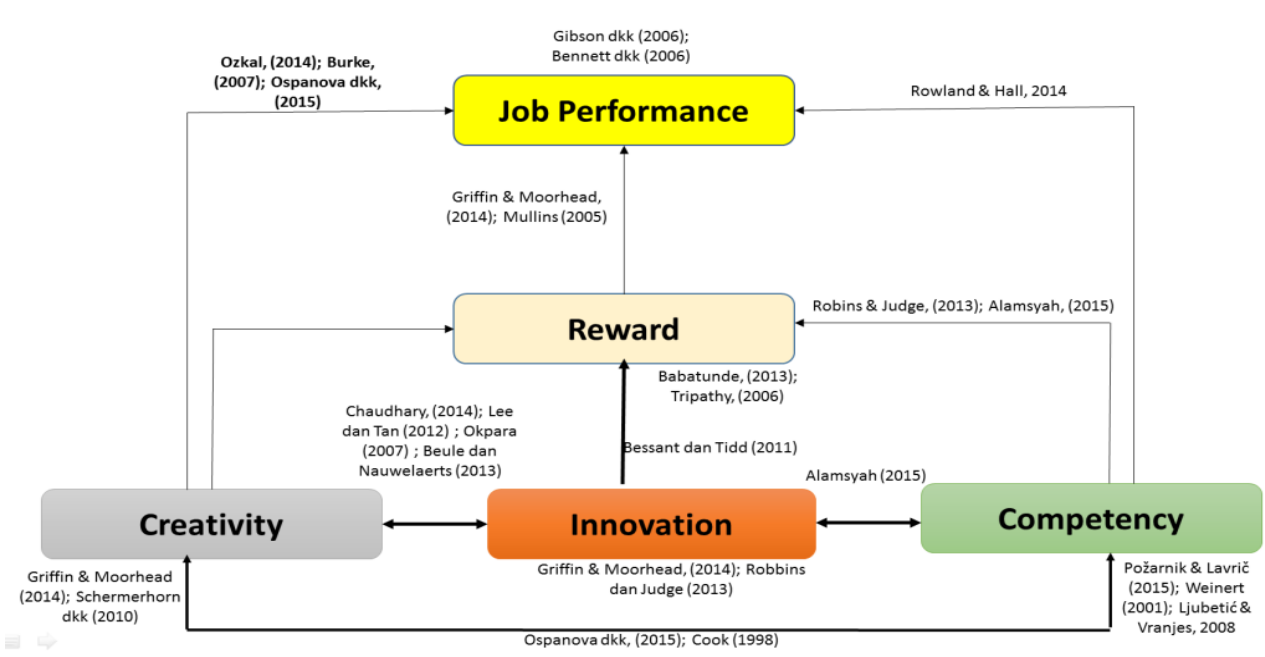

Figure 3. Implementation Strategy for Teacher Framework

\section{Results and Discussion}

Performance is always associated with a reward system (Rowland \& Hall, 2014). It was agreed by some scholars that any kind of reward impact the performance as well as motivation gives impact on it. Reward is considered like an external motivation that may affect teachers' performance. There are some aspects surrounding performance that should be aware of its existence to make teachers develop their performance. The best performance, growth opportunities and challenges, recognition and appreciation of non-cash is more effective motivator than money (Uzona, 2013). Performance-based rewards have a positive influence on motivation, morale, and commitment (Joo et al, 2012). An empathy reflected genuine concern and interest through employee suggestions and innovations that could be operationalized through a reward system. The role of the leader set the organization's vision, giving reward and the appropriate punishment and to supervise the overall activities of the employees. Team performance is a tribute. The reward system is directed as a result of the team not just individual performance (Luthan, 2011). Performance relationship and the reward will be stronger if people feel that performance is rewarded. High motivation if rewards for high performance and meet the requirements that was consistent with individual goals (Robin \& Judge, 2013).

There is a moderate positive correlation between creativity encourage teacher behavior 
and self-confidence (Ozkal, 2014). There is significant positive correlation between the issues of global citizenship within the relevant components with creativity. Components of global citizenship can predict creativity in humanities teachers. There is a relationship between issues of global citizenship, global specific topics, the issue of global communications, global cultural issues, global participation and creativity of teachers (Divsalar \& Soleymanpour, 2014). Lee and Tan (2012) concluded that creativity influence on the implementation of innovative. There is improved performance when an increased motivation to the environment done. Increased confidence when supervision is done and the facilities provided such as education, training, welfare, wages and bonuses to improve employee morale (Chaudhary, 2014). The empirical support and positive contribution have learning competency model-related individuals and organizations. Value management competence and capability management development program to improve the competence (Rowland \& Hall, 2014).

\section{Conclusion}

The strategies for teachers' framework were implemented through the series of programs, budgeting and procedures to improve the job performance through rewards for teachers that have creativity, innovation and competence become very urgent to begin immediately. The change of circumstances globally and the development of turbulence and unstable environmental in all fields including education sector requires the need to always do the changes and improvements made continuously including through the implementation of creativity, innovation and competence. Optimization in the development of creativity, innovation and competence to produce qualified teachers and have a competitive advantage in the field of education. Therefore, the appreciation implemented for the quality teacher as an added value and excellence in achieving better performance.

Expectations theory predicts that employees will exert effort better if you know a strong relationship between effort and performance, performance and rewards, as well as the rewards and satisfaction for private purposes. Every relationship is influenced by other factors (Robin \& Judge, 2013). Reward teacher became one of the demands in improving job performance for the development of national education. Teacher's reward was an appreciation for teachers based on merit or the superior performance given both individuals and institutions in the form of material or oral. Creative teacher is able to create ideas, creativity and new ideas in the development of learning systems. Changes and new development learning system better knowledge, skills and experience to improve the education system be the goal of innovation teacher. Competent teachers have the ability, skills and work attitudes in accordance with established standards.

Learning generally requires creativity and innovation, not only adapt to change but to anticipate the changes. Empowerment encourages innovation because the employee has the authority to try new ideas and make decisions that generate new ways of doing things (Luthan, 2011). The high creativity, innovation and competence of teachers in the learning system will increase the number and types of rewards obtained so as to encourage better performance. To improve job performance is happen increased, the teachers are required to have various types of rewards through the development of creativity, innovation and its competence. Through various types of rewards earned the teacher, then the teacher is indicated with creativity, innovation and superior 
competence. The contribution of teachers in the race is such as training, as well as their perceived minimal training so that performance is not maximized. Governments have an obligation to improve performance of teachers through the provision of various variants of competition and training initiated by both central and local governments by reward the fullest extent. As an implementation strategy in granting rewards to the teachers and the government should create a program, budget and procedures are structured and transparent so that the variety and types of rewards based on creativity, innovation and competence in order to create a better teacher achievement. To develop teachers' creativity, innovation, and competence should be likened to a researcher with the research results that can be given recognition and high appreciation for the work that he achieved accomplishments.

\section{REFERENCES}

Acton, A. (2013). Issues in Business, Occupational, and Creative Psychology. Georgia: Scholarly Editions.

Afuah, A. (2009). Strategic Innovation, New Game strategies for Competitive Advatage. New York Routledge.

Alamsyah, T. (2015). Tunjangan Profesi Guru Akan Diberikan Sesuai Capaian Prestasi. Diakses 29 September 2015 dari http://kemdikbud.go.id/kemdikbud/node/ 4320

Armstrong, M. (2012). Armstrong's Handbook of Reward Management Practice: Improving Performance through Reward, $4^{\text {th }}$ Edition. London: Kogan Page.

Babatunde, T. (2013). Reward: A Biblical Perspective. Texas: Trendy Publishing.

Bandur, A. (2014), Penelitian Kualitatif : Metodologi, Desain \& Teknik Analisis Data Dengan NVIVO 10, Mitra Wacana Media, Jakarta.
Bennett, W., Lence, C. E., \& Woehr, D. J. (2006). Performance Measurement: Current Perspective and Future Challenges. New York: Routledge.

Bessant, S. \& Tidd, J. (2011). Innovation and Intrepeneurship. West Sussex : John Wiley $\&$ Son.

Beule \& Nauwelaerts. (2013). Innovation and Creativity, Pillar of the Future Global Economy. New York : Edward Elgar Publishing Limited.

Bukvić, Z. (2014). Teacher Competency for Inclusive Education. The European Journal of Social and Behavioural Sciences, eISSN: 2301-2811, pp. 1585-1590.

Burke, C. (2007). Inspiring spaces: creating creative classrooms. Curriculum Briefing, 5 (2), 35-39.

Chaudhary, P. (2014). A Study over Expectancy Theory of Motivation in Small Scale Industries in NCR. International Journal of Research \& Development in Technology and Management Science, Vol. 21.

Cook, P. (1998). The Creativity Advantage, Is Your Organization The Leader of The Park?. Journal Industrial and Commercial Training, 30 (5).

Crick, D. R. (2008). Pedagogy for citizenship. In F. Oser \& W. Veugelers (Eds.), Getting involved: Global citizenship development and sources of moral values. Rotterdam: Sense Publishers.

Divsalar, H., \& Soleymanpour, J. (2014). The Relationship of Global Citizenship Issues and Organizational Creativity of Humanities Teacher in High School of Mazandaran Province. Kuwait Chapter of Arabian Journal of Business and Management Review, 3 (7), 141-152. 
Duin, P. (2006). Qualitative Futures Research for Innovation. Amsterdam: Eburon Academic Publishers.

Fleith, D. (2000). Teacher and student perceptions of creativity in the classroom environment. Roeper Rev. 22 (3), 148154.

Gibson, Ivancevich, Donnely, \& Konopaske. (2006). Organizations Behavior Structure. New York: Mc-GrawHill.

Griffin, R. W., \& Moorhead, G. (2014). Organizational Behavior, Managing People and Organizations. Canada: South Western, Cengage Learning.

Hema Malini, P. H., and Washington, A. (2014). Enjoyment the expected and valued reward ultimately leads to good quality of work life Employees' Motivation and Valued Rewards as a Key to Effective QWL- from the Perspective of Expectancy Theory. TSM Business Review, 2 (2), 4554.

Jeschke \& Hees. (2013). Automation, Communication and Cybernetics in Science and Engineering. Berlin: Springer Verlag.

Jex, S. M. Organizational Psychology: A Scientist-Practitioner Approach. New York: John Wiley \& Sons.

Joo, H., Lee, S., \& Jung, S. (2012). Performance-Based Reward for Teacher: Teachers Perceptions of Their Motivation. Research in Higher Education Journal.

Kusumah, W. 2009. Menjadi Guru Kreatif Melalui Karya Tulis Ilmiah. Diunduh 29 Maret 2015 dari http://wijayalabs.com/2009/04/20/menjad i-guru-kreatif-melalui-karya-tulis-ilmiah
Lee, L. Y., \& Tan, E. (2012). The Influences of Antecedents o Employee Creativity and Employee Performance: A Meta Analytic Review. Interdisciplinary Journal of Contemporary Research in Business, 4 (2).

Ljubetić, M., \& Vranješ, K. V. (2008). Pedagogical (in) competence of teachers. Educational science, 10 (1), 209-230.

Luthan, F. (2011). Organizational Behavior: An Evidence-Based Approach, Twelft Edition. New York: McGraw-Hill.

Martin. (2008). Creativity: Ethics and Excellence in Science. Lanham: Rowman \& Littlefield Publishing Group.

Mullins, L. (2005). Management and Organizational Behavior, Seventh Edition. London : Prentice Hall.

Mumford, M. (2012). Handbook of Organizational Creativity. Oxford : Elsevier.

Munthe, A. P. (2013). Guru Bersertifikat Minus Prestasi. Diunduh 29 September 2015 dari http://www.kabarindonesia.com /beritaprint.php

Okpara, F. (2007). The Value of Creativity and Innovation in Intrepreneurship. Journal of Asia Entrepreneurship and Sustainability, III (2).

Ospanova, B. A., Redlikh S. M., Sagdullaev I. I., Tashbulatova A. E., Abdulhakov A. B., \& Dadashov D. T. (2015). Methods of Developing of the Prospective Teacher's Creativity. Asian Social Science, 11 (13), 310-315. ISSN 1911-2017 E-ISSN 19112025.

Ozkal, N. (2014). Relationships between teachers' creativity fostering behaviors and their self-efficacy beliefs. Educational Research and Reviews. 9 (18), 724-733. 
Pitsis, Simpson \& Dehlin. (2012). Handbook of Organizational and Managerial Innovation, Massachussets: Edward Elgar Publishing, Inc.

Požarnik, B. M., \& Lavrič, A. (2015). Fostering the Quality of Teaching and Learning by Developing the "Neglected Half" of University Teachers' Competencies. CEPS Journal, 5 (2), 73-93.

Robins, S. P., \& Judge, T. A. (2013). Organizational Behavior, Fifteenth Edition. New Jersey: Pearson Education Inc.

Rose, M. (2014). Reward Management. London: Kogan Page Limited

Rowland, C., \& Hall, R. (2014). Management Learning, Performance and Reward: Theory and Practice Revisited. Journal of Management Development. 33 (4), 342356.

Runco, M. (2007). Creativity, Theories and Themes: Research, Development, and Practice. Oxford: Elsevier.

Sattler, M. (2011). Excellence in Innovation Management: A Meta-Analytic Review on the Predictors of Innovation Performance. Germany: Gabler Verlag.

Schermerhorn, J. R., Hunt, J., \& Osborn, R. N. (2010). Organizational Behavior. New York: John Wiley.

Sirait, J. T. (2006). Memahami Aspek-Aspek Pengelolaan Sumber Daya Manusia Dalam Organisasi. Jakarta: PT Grasindo.
Stamm, B. (2008). Managing Innovation, Design and Creativity, $2^{\text {nd }}$ Edition. West Sussex: John Wiley \& Sons.

Suud, M. (2012). Guru Diharapkan Lebih Inovatif Dalam Mengajar. Diakses 29 September 2015 dari http://edukasi.kompas.com/read/2012/03/ 21/12313075/Guru.Diharapkan.Lebih.In ovatif.dalam.Mengajar

Tomlinson, H. (2000). Proposals for Performance Related Pay in English Schools, School Leadership and Management, 20 (3), 281-298.

Tripathy, K. (2006). Study on the Work life of BPO Employees and the Various Human Resource Practices in a BPO - A Case Study of Convergys. Online website: http://www.indianmba.com/Faculty_Colu $\mathrm{mn} / \mathrm{FC} 391 /$ fc391.html

Undang-Undang Republik Indonesia No. 14 Tahun 2005 Tentang Guru dan Dosen.

Uzonna, U. R. (2013). Impact of motivation on employees' performance: A case study of Credit West Bank Cyprus, Journal of Economics and International Finance, 5 (5), 199-211.

Weinert, F. E. (2001). Concept of Competence: A Conceptual Clarification

White \& Bruton. (2011). The Management of Technology and Innovation: A Strategic Approach. South Western: Cengage Learning. 